\title{
A normoglykaemia elérésének korlátai inzulinkezelt 2-es típusú cukorbetegekben
}

\author{
Ferencz Viktória dr.* . Domján Beatrix dr.* . Gerő László dr. \\ Tänczer Tímea dr. - Tabák Gy. Ádám dr. \\ Semmelweis Egyetem, Általános Orvostudományi Kar, I. Belgyógyászati Klinika, Budapest
}

\begin{abstract}
Az inzulinkezelés a cukorbetegség leghatékonyabb kezelési módja. A microvascularis szövődmények kockázatának egyértelmű csökkentése és az esetleges hosszú távú cardiovascularis előnyök elérésének azonban ára van: a (súlyos) hypoglykaemia kockázata 2-3-szorosára nő, továbbá az inzulinkezelt betegek testsúlya gyorsabban növekszik, mint az egyéb kezelésben részesülőké. Egy vizsgálatban ráadásul az intenzív glykaemiás kezelés mellett (ami gyakrabban igényelt inzulint) növekedett az összmortalitás is. Jól ismert ezeken kívül az inzulin növekedési faktorszerú hatása, ami fokozott mitogenitást eredményezhet. Ezen potenciális mellékhatások mind a beteg, mind az orvos részéről gátat szabhatnak az inzulinterápia elkezdésének. A közleményben a szerzők bemutatják, hogy a cukorbetegség diagnózisakor alkalmazott átmeneti intenzív inzulinkezelés hosszú távú remissziót eredményezhet. Tárgyalják továbbá az inzulinkezelés elkezdésének optimális módját (napi egyszeri bázisinzulin), illetve az intenzifikálás lehetőségeit is. Kitérnek az analóg inzulinok farmakokinetikai előnyeire, és bemutatják, hogy az új bázisanalógok mellett hasonló hatékonyság érhető el, mint a humán inzulinnal, miközben a hypoglykaemia kockázata körülbelül 20-30\%-kal csökken. Orv. Hetil., 2015, 156(36), 1443-1450.
\end{abstract}

Kulcsszavak: inzulinkezelés, normoglykaemia, előnyök, hátrányok

\section{Factors limiting glycaemic control in insulin treated type 2 diabetes}

Insulin therapy is the most effective treatment of diabetes. It is proven to prevent microvascular disease and likely to decrease the risk of cardiovascular complications. However, these benefits are associated with a 2-3 times increased risk of hypoglycaemia and a faster weight gain compared to other antidiabetic medications. In addition, one study found elevated all-cause mortality among patients on intensive therapy (requiring more frequent insulinisation). Insulin has growth factor properties that may translate to increased mitogenicity. These factors could prevent the medical team or the patient from initiation or intensification of insulin therapy. The authors describe evidence on long-term remission related to transient intensified insulin therapy at diabetes diagnosis. The currently recommended method of insulin initiation is once daily basal insulin treatment that offers different schedules for intensification. The authors review the pharmacokinetics of analogue insulins that translate to similar efficacy to human insulins with a 20-30\% lower risk of hypoglycaemia.

Keywords: insulin therapy, normoglycaemia, benefits, limitations

Ferencz, V., Domján, B., Gerö, L., Tänczer, T., Tabák, Gy. Á. [Factors limiting glycaemic control in insulin treated type 2 diabetes]. Orv. Hetil., 2015, 156(36), 1443-1450.

(Beérkezett: 2015. június 25.; elfogadva: 2015. július 23.)

*A szerzők megosztott első szerzőként egyenlő mértékben járultak hozzá a közlemény elkészítéséhez. 


\section{Rövidítések}

ACCORD $=$ Action to Control Cardiovascular Risk in Diabetes; $\mathrm{ADVANCE}=$ Action in Diabetes and Vascular Disease: PreterAx and DiamicroN MR Controlled Evaluation; BMI = body mass index; $\mathrm{CI}=$ konfidenciatartomány; $\mathrm{CV}=$ cardiovascularis; DCCT $=$ Diabetes Control and Complications Trial; $\mathrm{HR}=($ hazard ratio) relatív hazárd; $\mathrm{NPH}=$ Neutralis Protamin Hagedorn; ORIGIN = Outcome Reduction with an Initial Glargine Intervention; PROactive $=$ PROspective pioglitAzone Clinical Trial In macroVascular Events; UKPDS = United Kingdom Prospective Diabetes Study; VADT = Veterans Affairs Diabetes Trial; 4T = Treating to Target in Type 2 Diabetes

\section{A normoglykaemiára törekvő kezelés bizonyított előnyei}

Az elmúlt évtizedek nagy diabetológiai vizsgálatai bizonyították, hogy az intenzifikált terápiák mellett (a vércukorértékek normalizálásával) a microvascularis diabeteses szövődmények kockázata markánsan csökkenthetô mind 1-es, mind 2-es típusú cukorbetegségben. Az 1\%-nyi $\mathrm{HbA}_{1 \mathrm{c}}$-javulás mellett elérhető 15-35\%-os rizikócsökkenés olyan számottevő, hogy a normoglykaemiára való törekvés hosszú időn keresztül megkérdőjelezhetetlen dogma maradt a diabetológiában, és elérése minden szempontból prioritást élvezett a gondozás során (1. táblázat) $[1,2,3]$.

Az UKPDS közel 10 éves követése során frissen felfedezett 2-es típusú cukorbetegeket randomizáltak intenzív és konvencionális vércukorkontrollt célzó csoportokba. Az intenzív ágon a tünetmentesség elérése mellett igyekeztek az éhomi vércukrot $6 \mathrm{mmol} / \mathrm{l}$, az étkezések előtti vércukrot 4-7 mmol/l közötti tartományban tartani. Amennyiben a fenti célok szulfanilurea- vagy inzulin-monoterápia mellett nem teljesültek, akkor metformin, illetve komplex inzulinrezsim bevezetését kezdeményezték. A konzervatív ágon ugyanakkor sokkal megengedőbb célokat definiáltak, és a kezelést életmódi tanácsokkal kezdték el. Az ideális testsúly elérését, 15 mmol/l alatti éhomi értéket és tünetmentes állapotot tûztek ki célul. A terápiás eszköztár kezdetben a diétás kezelésből állt, amelyet gyógyszeres terápia bevezetése követett a fenti célértékek meghiúsulása esetén [2].

1. táblázat | A diabetesszel összefüggő késői szövődmények kockázatának csökkenése és az elért glykaemiás értékek intenzifikált kezelés mellett $[1,2,3]$

\begin{tabular}{|c|c|c|c|}
\hline \multirow{2}{*}{$\begin{array}{l}\text { Vizsgált paraméter } \\
\text { javulásának mértéke (\%) }\end{array}$} & \multicolumn{3}{|c|}{ Vizsgálat } \\
\hline & $\begin{array}{c}\text { DCCT } \\
{[1]}\end{array}$ & $\begin{array}{c}\text { Kumamoto } \\
\text { Study [3] }\end{array}$ & $\begin{array}{l}\text { UKPDS } \\
\text { [2] }\end{array}$ \\
\hline $\mathrm{HbA}_{\mathrm{lc}}$ & $9 \rightarrow 7,2$ & $9 \rightarrow 7$ & $8 \rightarrow 7$ \\
\hline Retinopathia & 63 & 69 & $17-21$ \\
\hline Nephropathia & 54 & 70 & $24-33$ \\
\hline Neuropathia & 60 & Javult & - \\
\hline Cardiovascularis betegség & 41 (NS) & - & $16(\mathrm{NS})$ \\
\hline
\end{tabular}

Az intenzív ágon a kezelés megkezdését követően a $\mathrm{HbA}_{1 \mathrm{c}}$ értéke átmeneti javulást mutatott, és elérte a normáltartomány felső határát $(6,2 \%)$, majd ezt követően fokozatosan emelkedett és a vizsgálat végén $8 \%$-ig nőtt. Ezzel szemben a konzervatív ágon a $\mathrm{HbA}_{1 c}$-érték folyamatosan emelkedett 7-ról 9\%-ra. Ennek megfelelően a két kezelési ág $\mathrm{HbA}_{\mathrm{lc}}$-értéke között átlagosan $0,9 \%$ volt a különbség. Az intenzív kezelés mellett a microvascularis szövődmények szignifikánsan ritkábban fordultak elő, mint a konzervatív ágon [2].

Az UKPDS és a DCCT randomizált fázisának lezárásakor ugyan nem sikerült a macrovascularis diabeteses szövődmények kockázatában szignifikáns csökkenést kimutatni, azonban a résztvevók további passzív követése a korai normoglykaemiára törekvő kezelés késői kedvező hatására hívta fel a figyelmet. Miközben egyik vizsgálatban sem volt a $\mathrm{HbA}_{\mathrm{lc}}$-értékben kimutatható különbség a követés 2-3. évétől, a cardiovascularis végpontok előfordulása 15-60\%-kal csökkent. Ezen vizsgálati eredmények vezettek a kardiometabolikus terápiás memória fogalmának elterjedéséhez, ami a korai szoros glykaemiás kontroll késői kedvező micro- és macrovascularis hatását jelenti. Ennek ismeretében célszerúnek tûnik már a diagnózis felállításakor olyan hatékony terápiát választanunk (például inzulinkezelés), ami elősegíti ennek elérését $[4,5,6]$.

\section{Az intenzív inzulinkezeléssel járó kockázatok}

\section{Hypoglykaemia}

A hypoglykaemia következtében kialakuló direkt károsodás, majd az ennek hatására bekövetkező szervezeti válaszreakció (ami a vércukorérték normalizálására törekszik) számos kedvezőtlen hatással bír. Kiemelendő a gyulladásos markerek szintjének fokozódása, az endothelialis diszfunkció (és a következményes vasoconstrictio), a sympathicoadrenalis válaszreakció (ritmuszavarok, hemodinamikai változások, fokozott kardiális terhelés, növekvő oxigénszüksséglet) és a fokozott thrombosiskészség (alvadási faktorok, thrombocyta-neutrophil diszfunkció) [7].

Az UKPDS vizsgálat teljes időtartama alatt az intenzív ágon több beteg esett át egy vagy ismételt súlyos, illetve nem súlyos hypoglykaemiás eseményen, mint a konzervatív ágon. Az egyes intenzíven kezelt ágak összehasonlításakor a legtöbb hypoglykaemia az inzulinkezelt betegekben volt megfigyelhetô. Megjegyzendő ugyanakkor, hogy a vizsgálat előrehaladtával a fokozatosan romló anyagcsere mellett a szulfanilurea okozta hypoglykaemiák száma csökkent. A bármely okból bekövetkező hypoglykaemiák kockázata bizonyos vizsgálati időszakban akár harmincszorosa is volt a konzervatív ágon csak diétás kezelésben részesülő betegekének [2].

Azok a nagy diabetológiai tanulmányok (ACCORD, VADT, ADVANCE), amelyek hosszú diabetestartamú 
betegekben vizsgálták az intenzív kezelés következményeit, egymástól eltérő abszolút kockázat mellett, a hypoglykaemiás események relatív kockázatának közel 2-3,5-szeres emelkedését mutatták ki intenzív terápia mellett a konzervatív kezeléshez képest $[8,9,10]$.

Megjegyzendő az is, hogy l-es típusú diabeteses személyekben szintén körülbelül megduplázódik a hypoglykaemiás események előfordulása intenzív kezelés mellett a DCCT tanulmány eredményei szerint [4].

\section{Fokozott vércukor-pariabilitás}

Epidemiológiai megfigyelések felvetik, hogy nem diabeteses személyekben a postprandialis vércukor emelkedése fokozott cardiovascularis és összmortalitással társul, miközben az éhomi vércukorral hasonló kapcsolat csak alig mutatható ki $[11,12]$. Ezek alapján logikusnak tünik, hogy az étkezés utáni magas vércukorkilengések cukorbetegekben is összefügghetnek a szövődmények megjelenésével.

Ugyanakkor az is nyilvánvalónak tünik, és irodalmi adatok alapján bizonyított, hogy magas vércukor-variabilitás mellett az átlagos vércukrok csökkentése a hypoglykaemiák kockázatának fokozódásával jár [13, 14, 15].

A glükózvariabilitás és a diabeteses szövődmények kapcsolatáról megoszlanak az irodalmi adatok. Egy szisztémás irodalmi áttekintés szerint 2-es típusú cukorbetegekben a megnövekedett vércukor-variabilitás fokozott retinopathia-, cardiovascularis és mortalitási kockázattal társult, ugyanakkor hasonló összefüggés nem volt igazolható l-es típusú betegekben. A postprandialis glükózcsúcsok ugyanakkor mindkét betegségtípusban kapcsolatban álltak a szövődmények kialakulásával [16].

\section{Testsúlynövekedés}

Az inzulinterápia egyik fó nemkívánatos hatása a testsúlygyarapodás. A hízás mértéke a kezelés első évében intenzifikált rezsim mellett közel 5\%, konvencionális kezelés során is mintegy 3\% volt a DCCT vizsgálatban. Hasonlóan 2-es típusú diabetesben is kimutatható a testsúly gyors emelkedése intenzív kezelés mellett az első évben (körülbelül $3 \mathrm{~kg}$ ), amelyet további fokozatos, de lassabb ütemü emelkedés követ (hozzávetőleg 0,5 kg/ év). A konzervatív ágon ugyanezen időszakban a testtömeg növekedése 2,5-3 kg volt. Mindezek alapján a normoglykaemia elérésének egyik ára a testsúly emelkedése $[2,17]$.

A testtömeg növekedése a cardiovascularis (CV) kockázati tényezők egyértelmű fokozódásával jár. Míg a legkisebb súlynövekedésen átesett betegekben általában 6-8\%-kal javultak a vérzsírok és nem változott a vérnyomás, addig a legnagyobb súlygyarapodást elszenvedő személyekben a vérzsírok 4-6\%-kal romlottak, és nagyjából 5\%-kal emelkedett a vérnyomás a DCCT vizsgálatban [18].
Egy mintegy 900 ezer személy ( 57 prospektív kohorsz) adatainak feldolgozásával készült, 8 éves megfigyelési időtartamot átölelő vizsgálat szerint a testtömegindex és a mortalitás J alakú összefüggést mutat. Mind a magas, mind az alacsony értékek fokozott kockázattal járnak, a legkedvezóbb a $22,5-25 \mathrm{~kg} / \mathrm{m}^{2}$ BMI-tartomány [19]. A túlsúly feletti tartományban a BMI $5 \mathrm{~kg} / \mathrm{m}^{2}$-rel nagyobb értéke 30\%-kal nagyobb összmortalitással és 40\%kal nagyobb vascularis halálozással jár [19].

A cardiovascularis események szempontjából a visceralis obesitas kiemelt jelentôséggel bír. Férfiakban $107 \mathrm{~cm}$ feletti haskörfogat mellett megduplázódik a cardiovascularis betegségek előfordulása a $84 \mathrm{~cm}$ alatti csoporthoz képest. Hasonlóan nókben a $101 \mathrm{~cm}$ feletti haskörfogat két és félszeres rizikónövekedést jelez a $76 \mathrm{~cm}$ alatti értékű személyekhez képest [20]. A cardiovascularis betegségek és a haskörfogat közötti összefüggés általában szorosabbnak adódott, mint a BMI-vel való kapcsolat [20, 21].

\section{Mortalitás}

Hemmingsen metaanalízise alapján 2-es típusú cukorbetegek intenzív kezelése nem növeli a betegek össz- vagy cardiovascularis mortalitását. A tanulmány 34912 beteg adatait dolgozza fel, akik közül 18717 intenzív glykaemiás kontrollban, 16195 fó konzervatív kezelési rezsimben részesült. Az intenzív kezelési ágon a bármely okból bekövetkező halálozás (RR 1,00, 95\% CI 0,92-1,08), illetőleg a cardiovascularis mortalitás (RR 1,06, 95\% CI 0,94-1,21) nem különbözött a konzervatív ágon megfigyelttől. A negatív macrovascularis eredmények mellett a szerzők hangsúlyozzák a szigorúbb anyagcserekontroll kedvező microvascularis hatásait is. A metaanalízis ugyanakkor megerósítette, hogy intenzív kezelés mellett a hypoglykaemia kockázata fokozott, beleértve a súlyos hypoglykaemiák előfordulásának 118\%-os emelkedését (RR 2,18, 95\% CI 1,53-3,11) [22].

Egy korábbi metaanalízis az intenzív anyagcserekontroll és a macrovascularis események közti összefüggést további végpontok tekintetében is vizsgálta. Az intenzív ágon megfigyelt $0,9 \%$-kal alacsonyabb $\mathrm{HbA}_{\mathrm{lc}}$-érték mellett Ray és munkatársai azt találták, hogy az intenzív vércukorcsökkentő kezelés alkalmazásakor a nem fatális myocardialis infarctus előfordulása $17 \%$-kal $(95 \%$ CI $0,75-0,93)$ és a coronariabetegségé 15\%-kal (95\% CI 0,77-0,93) alacsonyabb volt, mint a konzervatív kezelés esetén. A stroke és a bármely okból bekövetkező halálozás azonban ebben a metaanalízisben is hasonló volt a két vizsgált csoportban. Az elemzésben az UKPDS, VADT, ACCORD, ADVANCE és a PROactive vizsgálatok szerepeltek, összesen 33040 résztvevővel [23].

Ezen metaanalízisek nem találtak összefüggést az intenzív kezelés és mortalitás között, annak ellenére, hogy az intenzív ágon minden vizsgálatban nőtt a hypoglykaemiák előfordulása, és a hypoglykaemiák előfordulása fokozott mortalitással járt [22, 23, 24, 25]. Az ACCORD vizsgálat intenzív terápiás karján a fokozott hypoglykae- 
mia kockázata mellett a bármely okból bekövetkező halálozás fokozódását tapasztalták, ami miatt a vizsgálat leállítására kényszerültek. Bár felmerült, hogy a két tényező között ok-okozati kapcsolat lenne, ezt nem sikerült bizonyítani. Ezek ellenére nem kérdéses, hogy a terápiaválasztáskor a hypoglykaemák lehetőség szerinti elkerülésére kell törekedni $[9,26]$.

$\mathrm{Az}$ anyagcsere mindenáron történő normalizálása vagy a „túlzottan szigorú” glykaemiás kontroll nem feltétlenül vezet kedvezőbb kimenetelhez. Ezt támasztja alá az angol háziorvosi praxisok adatainak felhasználásával készült elemzés is, ami szerint a $\mathrm{HbA}_{\mathrm{lc}}$ és a cardiovascularis, illetve a bármely okból bekövetkező halálozás közötti összefüggés U alakú, és minimumát 7-8,5\%-os értéknél éri el [27].

\section{Mitogén batás}

A cukorbetegek kockázata fokozott a colorectalis, emlő-, endometrium-, hepatocellularis, pancreas- és epehólyagdaganatok kialakulására. Ráadásul a daganatokkal összefüggő halálozás is emelkedett cukorbetegségben az átlagpopulációhoz viszonyítva $[28,29]$.

$\mathrm{Az}$ inzulinok jól ismerten növekedési hormonok, így mitogén hatásuk sem kérdéses. Ennek alapján pedig felmerül potenciális daganatkeltő hatásuk. A mitogén hatás hátterében az IGF-1-receptorhoz történő inzulin(analóg) kötődés áll. Feltételezhető, hogy az IGF-1-receptorhoz történő hosszabb kötődési idő, azaz a receptorról történő lassabb disszociáció, valamint a nagyobb receptoraffinitás egyaránt erélyesebb mitogén hatást gyakorol a sejtekre. A mitogenitás sejtproliferációt, antiapoptotikus hatást és fokozott invazivitást eredményezhet [30].

Ezzel szemben az inzulinreceptorhoz történő erélyesebb kötődés (nagyobb affinitás, hosszabb kötődési idő) erôteljesebb metabolikus választ ad [30]. Az egyes prandialis és bázis inzulinanalógok között jelentős különbségek lehetnek a fenti két receptorhoz történő affinitásban, a receptorokról való disszociációban, így a metabolikus és a mitogén hatás mértékében és arányában [31, 32].

A glargin inzulin nagyobb IGF-1-affinitása felvetette a fokozott mitogén hatás következtében a daganatos betegségek gyakoriságának fokozódását. Ugyanakkor a glargin inzulin nagy része már aktív metabolitként kerül a keringésbe, aminek IGF-1-kötődése nem kedvezőtlen. Ezt támasztják alá a nagy epidemiológiai tanulmányok is, amelyek nem találtak fokozott daganatkockázatot a glargin inzulin mellett, ső́t a vizsgálatok egy része a daganatok csökkent gyakoriságát találta $[33,34]$.

\section{A diagnóziskor megkezdett inzulinkezelés potenciális előnyei 2 -es típusú cukorbetegségben}

Az inzulinterápia bevezetése többnyire az egyéb terápiák sikertelensége esetén történik 2-es típusú cukorbetegek- ben. A kezelőorvos és a beteg ellenállása vagy bizonytalansága évekig halogathatja az inzulinterápia bevezetését. Az orális szerek dózisának fokozatos emelése és a nem inzulintípusú gyógyszeres terápiák kombinálása, nemritkán három vagy akár négy hatóanyag együttes adásának elégtelensége vezet az inzulinkezelés elkezdéséhez. A beteg részéről az inzulinadás kezelés gátja lehet a félelem az injekciós kezeléssel járó kényelmetlenségtől, a hypoglykaemiától, illetve a testsúly gyarapodásától. A kezelőorvos részéről az inzulinterápia elkezdésének gátat szabhat a bevezetéshez szükséges időigényes betegedukáció biztosításának nehézsége, az infrastruktúra, illetve a finanszírozás elégtelensége, a hypoglykaemia kezelhetőségével kapcsolatban megfogalmazódó szkepszis, valamint a terápiás rezsimmel kapcsolatos bizonytalanság $[35,36]$.

Ez a fajta gondolkodás magában hordozza annak a veszélyét, hogy a betegek szénhidrát-anyagcseréje az ismert diabetestartam egy jelentős részében célérték feletti, hiszen az előző terápia sikertelensége esetén történik csak terápiás előrelépés. Ennek megfelelően a beteg elveszti a korábbiakban bemutatott metabolikus memória kialakításának lehetőségét is. Ezt számos epidemiológiai vizsgálat is bizonyítja, amelyek szerint a terápiaváltás az általában elfogadott $\mathrm{HbA}_{1 \mathrm{c}}$-értéket $(\sim 7 \%)$ jóval meghaladó szintnél (körülbelül 9\%) történik csak, és a betegek legalább fele 5 évet tölt el $7 \%$ feletti $\mathrm{HbA}_{\mathrm{lc}}$-vel, mielőtt a második orális gyógyszert bevezetnék [37, 38].

A közvetlenül a 2-es típusú cukorbetegség diagnózisának felállítását követően elkezdett, és többnyire csak átmenetileg adagolt inzulin bevezetését követően a betegek jelentős része inzulin adása nélkül is euglykaemiás állapotban maradhat akár éveken át [39]. Ez a kezelési módszer alkalmas volt a betegek közel 90\%-ában az euglykaemia elérésére 2-4 hét alatt, és a betegek kétharmada nem igényelt semmilyen kezelést 6 hónappal később, és ez az arány $50 \%$ körül volt egyéves követés esetén is [39, 40]. Az eddigi legnagyobb randomizált, kontrollált vizsgálatban ez az átmeneti inzulinkezelés inzulinpumpát vagy napi többszöri inzulinadagolást jelentett, és a normoglykaemia eléréséhez 4-6 napra volt szükség. A kontrollként alkalmazott szulfanilurea is hatékonynak bizonyult, bár a hatás kifejlődéséhez hosszabb időre volt szükség, azonban az 1 éves követés során ez utóbbi csoportban jelentősen romlott a $\beta$-sejt-funkció [40].

A korán megkezdett inzulinkezelés biztonságosságát és átlagosan 7 éven át tartó hatékonyságát jól bizonyítják az ORIGIN vizsgálat eredményei, miszerint a korán megkezdett inzulinkezelés mellett stabilan 6\% körüli $\mathrm{HbA}_{1 \mathrm{c}}$-érték volt tartható éveken át, minimális súlynövekedés mellett (1,6 vs. 1,1 kg a konzervatív ágon). Súlyos hypoglykaemiát csak a betegek $1 \%$-ában észleltek (vs. 0,31 a kontrollcsoportban), és nem merült fel sem cardiovascularis, sem daganatos betegségekkel kapcsolatos biztonságossági aggály [34]. 


\section{$\mathrm{Az}$ inzulinkezelés szülkségessége a 2-es típusú diabetest jellemző $\beta$-sejt-funkció-csökkenés ismeretében}

Az utóbbi évek irányelvei személyre szabott célok kitűzését javasolják. Ennek megállapításakor számos szempont mérlegelése szükséges. Ezek közül kiemelendő a diabetes tartama, a beteg kora és várható élettartama, a komorbiditások jelenléte, a hypoglykaemia-érzés hiánya. Ugyanilyen fontos lehet ugyanakkor a rendelkezésre álló források, a beteget támogató környezet megítélése és a beteg hozzáállása is. Mindezek alapján nyilvánvaló, hogy a modern cukorbeteg-ellátás a beteg és a kezelőorvos kétirányú kommunikációja alapján, a beteg tájékozott döntésének eredményeképpen jön létre [41].

Míg az eloórt célérték meghatározásában igen nagy szabadsága lehet a betegnek és a kezelőorvosnak, addig a betegség természetes lefolyását egyelőre, sajnos, csak kevéssé lehet befolyásolni. A 2-es típusú cukorbetegség progressziója a hasnyálmirigy- $\beta$-sejtek fokozatos funkcióvesztésének következményének tudható be, ami már a betegséget megelőzó években is egyértelműen igazolható. A progresszióval párhozamosan a külső forrásból származó inzulinszükséglet egyre növekszik, amely az inzulinkezelés folyamatos bővítésének kórélettani magyarázatát jelenti $[42,43,44]$.

Az inzulinkezelés bevezetésével kapcsolatosan éveken át nagyfokú bizonytalanság jellemezte a diabetológusokat. Egyformán elterjedt volt kezdeti terápiaként a napi l-szer adott bázisinzulin, az előkevert inzulin napi kétszeri adása, illetve az étkezésekkor adagolt gyors hatású inzulinok alkalmazása. Egy 2009-ben megjelent metaanalízis szerint mind a prandialis, mind a bifázisos inzulin kedvezóbb anyagcserekontrollt eredményez, ugyanakkor mellettük valamivel több a súlygyarapodás és a hypoglykaemia kockázata. Ezen vizsgálatok többsége azonban csak rövid ideig követte a betegeket, így a cukorbetegség hosszú távú alakulásával kapcsolatosan csak korlátozott válaszokat adtak [45].

A 4T [46] vizsgálat 3 éves követése azonban egyértelmúvé tette, hogy a kezdeti kezeléstől függetlenül hosszú távon a betegek legalább kétharmada napi többszöri inzulinadagolást igényel. Ugyanakkor a bázisinzulinnal megkezdett kezelés mellett volt a legkisebb a súlygyarapodás és legalacsonyabb a hypoglykaemia-kockázat, miközben a harmadik év végére a $\mathrm{HbA}_{\mathrm{lc}}$-értékek gyakorlatilag nem különböztek a csoportokban $[47,48]$.

A fenti vizsgálatok fényében az inzulinkezelés bevezetésének preferált lehetősége a napi egyszeri bázisinzulin alkalmazása, amelynek legolcsóbb módját az NPH inzulin esti, lefekvéskor vagy vacsoraidőben történő adagolása jelenti. Míg a treat-to-target típusú vizsgálatok egyértelmúen bizonyították, hogy az NPH és a bázisanalóg inzulinok hasonlóan hatékonyak mind az éhomi vércukor, mind a $\mathrm{HbA}_{1 \mathrm{c}}$-célérték elérésében, az NPH típusú bázisinzulin egyértelmû hátránya a készítmény csúcshatása, amely a lefekvéskori adás mellett éjszakai hypogly- kaemia előfordulását idézheti elő $[46,49,50,51]$. Az NPH inzulin a fiziológiás igények szerinti szükséglettől eltérő hatásprofillal rendelkezik, amely miatt napi többszöri (akár háromszori) adagolásra lehet szükség [52]. A nagyobb dózisigény esetén a hypoglykaemia veszélye is fokozott.

A modern bázisanalógok csúcshatás nélküli vagy kisebb csúcshatással bíró inzulinok, alkalmazásuk nagyban csökkenti a hypoglykaemiák előfordulását. További kedvező tulajdonságuk, hogy fokozott veszéllyel járó éjszakai hypoglykaemiák kockázatát lényegesen jobban csökkentik, mint a könnyebben észlelhető és kezelhető nappali hypoglykaemiákét $[46,49,50]$. Természetesen az alacsonyabb hypoglykaemia-incidencia azonos $\mathrm{HbA}_{\mathrm{lc}}$-érték mellett azt is jelentheti a klinikai gyakorlatban, hogy az NPH-nak megfelelő hypoglykaemia-gyakoriság mellett kedvezőbb anyagcserehelyzet érhető el [53].

A jelenleg fejlesztés alatt álló bázisinzulin-készítmények mind megnyújtott hatástartamukban, mind csúcshatásuk hiányában, mind pedig a hatás variabilitásának mértékében felülmúlják az eddig alkalmazott készítményeket. Ez klinikailag elsősorban a hypoglykaemia-kockázat glargin inzulinhoz képesti további 20-30\%-os csökkenésében nyilvánul meg hasonló anyagcserehelyzet mellett. Az új generációs bázisinzulinok közül biztonsági szempontból kiemelhető a magasabb koncentrációjú glargin, az úgynevezett U-300 glarginkészítmény, amelynek hatóanyagával már másfél évtizedes biztonságossági adatok állnak rendelkezésre, ugyanakkor klinikai tulajdonságai egyértelmúen kedvezőbbek a $100 \mathrm{E} / \mathrm{ml}$ koncentrációjú glarginnál $[54,55,56,57]$.

Hosszú diabetestartam esetén a hasnyálmirigy inzulinszekréciós kapacitása tovább csökken, így a hagyományos orális antidiabetikumok adása mellett glykaemiás kontroll elégtelenné válhat. Az UKPDS vizsgálat eredményei szerint ez a diagnózis felállításától kezdődően évente körülbelül a betegek $10 \%$-át érinti $[58,59]$. Néhány év elteltével a bázisinzulin önmagában történő adása is terápiás sikertelenséghez vezethet, ilyenkor étkezés előtti inzulin vagy esetenként egyéb prandialis készítmény (például GLP-1-analóg) adása válhat szükségessé $[26,41]$.

A prandialis inzulin bevezetésének legegyszerúbb módja a napi kétszeri adagolású előkevert inzulinkészítmény, amely megközelítőleg biztosítani tudja a reggeli és vacsora utáni inzulinszükségletet. Mind a humán, mind az analóg előkevert készítmény kifejezett hátrányát jelenti a rugalmatlan életmód (az ebéd időpontja gyakorlatilag nem módosítható), és a déli étkezés okozta vércukor-emelkedés. A napi kétszeri inzulinadás másik, hazánkban kevéssé elterjedt módja a bázisanalóg mellé adott napi egyszeri étkezési inzulin. Ilyenkor a prandialis inzulin adását a legnagyobb szénhidráttartalmú étkezés elé kell időzíteni. Ez a rendszer lehetőséget ad a kezelés könnyű bővítésére a további étkezések előtt adott inzulinok bevezetésével $[36,41,60]$. 
A napi több mint kétszeri inzulinadás számos készítmény kombinációját jelentheti. Ez a kezelési rezsim lehetőséget teremthet a bázis- és az étkezési bólusinzulinok elkülönítésére. Hátránya, fóleg humán inzulin adása esetén, a viszonylag kötött életmód és a fokozott edukációs igény. A betegeknek az optimális inzulinadag kiszámolásához tudniuk kell az általuk használt inzulin farmakokinetikáját, farmakodinámiáját, és ismerniük kell az inzulin, az étkezés, illetve a fizikai aktivitás egymásra gyakorolt hatásait. További potenciális hátrányt jelenthet a vércukor rendszeres önellenőrzéséből adódó fokozott kényelmetlenség, a kezelést végző csapattal történő rendszeres kapcsolattartás és a beállított rendszer követelményeinek betartása. A napi többszöri kezelés előnye lehet, főképp az analóg prandialis és bázisinzulinok esetén, a páciens igényeihez adaptált rugalmas terápia [36, $41,60]$.

\section{Új fejlesztési irányok}

$\mathrm{Az}$ inzulinterápia hatékonyságának javítása a beadóeszközök fejlesztésén túl (beleértve az inzulinpumpa-kezelést, zárt rendszerű inzulinpumpa kialakítását) az inzulintípusok folyamatos evolúcióját is jelenti. A hatékony prandialis inzulinok iránti igény megteremtette a gyors, beadás után igen rövid időn belül kialakuló hatást és rövid hatástartamot biztosító ultragyors analóg inzulinokat.

A bázisinzulinok fejlesztése a csúcshatás minimalizálása mellett egyre elhúzódóbb hatástartamú készítmények fejlesztését célozta meg. További igen fontos szempont ezen gyógyszerek esetében is a biztonságosság, amely mind a cardiovascularis, mind a mitogén hatás tekintetében érvényes $[55,61]$.

Az inzulinok fejlesztésének célja mit sem változott az elmúlt közel 100 évben: a beteg biztonsága és a normoglykaemia elérése mellett a flexibilis, kényelmes életvitel biztosítása [62].

Anyagi támogatás: A közlemény megírása anyagi támogatásban nem részesült.

Szerzői munkamegosztás: F. V., D. B.: A szöveg első verziójának elkészítése, irodalomkutatás, a revíziók áttekintése és javítása. G. L., T. T.: Irodalomkutatás, a revíziók áttekintése és javítása. T. Gy. Á.: A cikk koncepciójának kialakítása, a szöveg első verziójának elkészítése, irodalomkutatás, a revíziók áttekintése és javítása. A cikk végleges változatát valamennyi szerző elolvasta és jóváhagyta.

Érdekeltségek: A szerzőknek nincsenek érdekeltségeik.

\section{Irodalom}

[1] The Diabetes Control and Complications Trial Research Group: The effect of intensive treatment of diabetes on the development and progression of long-term complications in insulin-dependent diabetes mellitus. N. Engl. J. Med., 1993, 329(14), 977986.

[2] UK Prospective Diabetes Study (UKPDS) Group: Intensive bloodglucose control with sulphonylureas or insulin compared with conventional treatment and risk of complications in patients with type 2 diabetes (UKPDS 33). Lancet, 1998, 352(9131), 837853.

[3] Obkubo, ., Kishikawa, H., Araki, E., et al.: Intensive insulin therapy prevents the progression of diabetic microvascular complications in Japanese patients with non-insulin-dependent diabetes mellitus: a randomized prospective 6-year study. Diabetes Res. Clin. Pract., 1995, 28(2), 103-117.

[4] The Writing Team for the Diabetes Control and Complications Trial/Epidemiology of Diabetes Interventions and Complications Research Group: Effect of intensive therapy on the microvascular complications of type 1 diabetes mellitus. JAMA, 2002, 287(19), 2563-2569.

[5] Holman, R. R., Paul, S. K., Bethel, M. A., et al.: Long-term follow-up after tight control of blood pressure in type 2 diabetes. N. Engl. J. Med., 2008, 359(15), 1565-1576.

[6] Jermendy, G.: Vascular memory: can we broaden the concept of the metabolic memory? Cardiovasc. Diabetol., 2012, 11, 44.

[7] Desouza, C. V., Bolli, G. B., Fonseca, V.: Hypoglycemia, diabetes, and cardiovascular events. Diabetes Care, 2010, 33(6), 13891394.

[8] Patel, A., MacMahon, S., Chalmers, J., et al.: Intensive blood glucose control and vascular outcomes in patients with type 2 diabetes. N. Engl. J. Med., 2008, 358(24), 2560-2572.

[9] Gerstein, H. C., Miller, M. E., Byington, R. P., et al.: Effects of intensive glucose lowering in type 2 diabetes. N. Engl. J. Med., 2008, 358(24), 2545-2559.

[10] Duckworth, W., Abraira, C., Moritz, T., et al.: Glucose control and vascular complications in veterans with type 2 diabetes. $\mathrm{N}$. Engl. J. Med., 2009, 360(2), 129-139.

[11] The DECOPE Study Group, on behalf of the European Diabetes Epidemiology Group: Glucose tolerance and cardiovascular mortality: comparison of fasting and 2-hour diagnostic criteria. Arch. Intern. Med., 2001, 161(3), 397-405.

[12] Nakagami, T.: Hyperglycaemia and mortality from all causes and from cardiovascular disease in five populations of Asian origin. Diabetologia, 2004, 47(3), 385-394.

[13] Cox, D. J., Kovatchev, B. P., Julian, D. M., et al.: Frequency of severe hypoglycemia in insulin-dependent diabetes mellitus can be predicted from self-monitoring blood glucose data. J. Clin. Endocrinol. Metab., 1994, 79(6), 1659-1662.

[14] Monnier, L., Wojtusciszyn, A., Colette, C., et al.: The contribution of glucose variability to asymptomatic hypoglycemia in persons with type 2 diabetes. Diabetes Technol. Ther., 2011, 13(8), 813-818.

[15] DeVries, J. H.: Glucose variability: where it is important and how to measure it. Diabetes, 2013, 62(5), 1405-1408.

[16] Nalysnyk, L., Hernandez-Medina, M., Krishnarajah, G.: Glycaemic variability and complications in patients with diabetes mellitus: evidence from a systematic review of the literature. Diabetes Obes. Metab., 2010, 12(4), 288-298.

[17] The DCCT Research Group: Weight gain associated with intensive therapy in the Diabetes Control and Complications Trial. Diabetes Care, 1988, 11(7), 567-573. 
[18] Purnell, J. Q., Hokanson, J. E., Marcovina, S. M., et al.: Effect of excessive weight gain with intensive therapy of type 1 diabetes on lipid levels and blood pressure: results from the DCCT. JAMA, 1998, 280(2), 140-146.

[19] Whitlock, G., Lewington, S., Sherliker, P., et al.: Body-mass index and cause-specific mortality in 900,000 adults: collaborative analyses of 57 prospective studies. Lancet, 2009, 373(9669), 1083-1096.

[20] Balkau, B., Deanfield, J. E., Després, J. P., et al.: International Day for the Evaluation of Abdominal Obesity (IDEA): a study of waist circumference, cardiovascular disease, and diabetes mellitus in 168,000 primary care patients in 63 countries. Circulation, 2007, 116(17), 1942-1951.

[21] De Hollander, E. L., Bemelmans, W. J., Boshuizen, H. C., et al.: The association between waist circumference and risk of mortality considering body mass index in 65- to 74-year-olds: a metaanalysis of 29 cohorts involving more than 58,000 elderly persons. Int. J. Epidemiol., 2012, 41(3), 805-817.

[22] Hemmingsen, B., Lund, S. S., Gluud, C., et al.: Targeting intensive glycaemic control versus targeting conventional glycaemic control for type 2 diabetes mellitus. Cochrane Database Syst. Rev., 2013, 11, CD008143.

[23] Ray, K. K., Seshasai, S. R., Wijesuriya, S., et al.: Effect of intensive control of glucose on cardiovascular outcomes and death in patients with diabetes mellitus: a meta-analysis of randomised controlled trials. Lancet, 2009, 373(9677), 1765-1772.

[24] Bonds, D. E., Miller, M. E., Bergenstal, R. M., et al.: The association between symptomatic, severe hypoglycaemia and mortality in type 2 diabetes: retrospective epidemiological analysis of the ACCORD study. BMJ, 2010, 340, b4909.

[25] Zoungas, S., Patel, A., Chalmers, J., et al.: Severe hypoglycemia and risks of vascular events and death. N. Engl. J. Med., 2010, 363(15), 1410-1418.

[26] American Diabetes Association: Standards of medical care in diabetes - 2014. Diabetes Care, 2014, 37(Suppl. 1), S14-S80.

[27] Currie, C. J., Peters, J. R., Tynan, A., et al.: Survival as a function of $\mathrm{HbA}(\mathrm{lc})$ in people with type 2 diabetes: a retrospective cohort study. Lancet, 2010, 375(9713), 481-489.

[28] Giovannucci, E., Harlan, D. M., Archer, M. C., et al.: Diabetes and cancer: a consensus report. Diabetes Care, 2010, 33(7), 1674-1685

[29] Coughlin, S. S., Calle, E. E., Teras, L. R., et al.: Diabetes mellitus as a predictor of cancer mortality in a large cohort of US adults. Am. J. Epidemiol., 2004, 159(12), 1160-1167.

[30] Kurtzhals, P., Schaffer, L., Sorensen, A., et al.: Correlations of receptor binding and metabolic and mitogenic potencies of insulin analogs designed for clinical use. Diabetes, 2000, 49(6), 9991005.

[31] Shukla, A., Grisouard, J., Ehemann, V., et al.: Analysis of signaling pathways related to cell proliferation stimulated by insulin analogs in human mammary epithelial cell lines. Endocr. Relat. Cancer, 2009, 16(2), 429-441.

[32] Mayer, D., Chantelau, E.: Treatment with insulin glargine (Lantus) increases the proliferative potency of the serum of patients with type-1 diabetes: a pilot study on MCF-7 breast cancer cells. Arch. Physiol. Biochem., 2010, 116(2), 73-78.

[33] Ruiter, R., Visser, L. E., van Herk-Sukel, M. P., et al.: Risk of cancer in patients on insulin glargine and other insulin analogues in comparison with those on human insulin: results from a large population-based follow-up study. Diabetologia, 2012, 55(1), 51-62.

[34] Gerstein, H. C., Bosch, J., Dagenais, G. R., et al.: Basal insulin and cardiovascular and other outcomes in dysglycemia. N. Engl. J. Med., 2012, 367(4), 319-328.

[35] Riddle, M. C.: Making the transition from oral to insulin therapy. Am. J. Med., 2005, 118(Suppl. 5A), 14S-20S.
[36] DeWitt, D. E., Hirsch, I. B.: Outpatient insulin therapy in type 1 and type 2 diabetes mellitus: scientific review. JAMA, 2003, 289(17), 2254-2264.

[37] Khunti, K., Wolden, M. L., Thorsted, B. L., et al.: Clinical inertia in people with type 2 diabetes: a retrospective cohort study of more than 80,000 people. Diabetes Care, 2013, 36(11), 34113417 .

[38] Brown, J. B., Nichols, G. A., Perry, A.: The burden of treatment failure in type 2 diabetes. Diabetes Care, 2004, 27(7), 15351540.

[39] Retnakaran, R., Drucker, D. J.: Intensive insulin therapy in newly diagnosed type 2 diabetes. Lancet, 2008, 371(9626), 17251726.

[40] Weng, J., $L i, \Upsilon$., Xu, W., et al.: Effect of intensive insulin therapy on beta-cell function and glycaemic control in patients with newly diagnosed type 2 diabetes: a multicentre randomised parallelgroup trial. Lancet, 2008, 371(9626), 1753-1760.

[41] Inzucchi, S. E., Bergenstal, R. M., Buse, J. B., et al.: Management of hyperglycemia in type 2 diabetes, 2015: a patient-centered approach: update to a position statement of the American Diabetes Association and the European Association for the Study of Diabetes. Diabetes Care, 2015, 38(1), 140-149.

[42] U.K. Prospective Diabetes Study Group: U.K. Prospective Diabetes Study 16: Overview of 6 years' therapy of type II diabetes: a progressive disease. Diabetes, 1995, 44(11), 1249-1258.

[43] Tabák, A. G., Jokela, M., Akbaraly, T. N., et al.: Trajectories of glycaemia, insulin sensitivity, and insulin secretion before diagnosis of type 2 diabetes: an analysis from the Whitehall II study. Lancet, 2009, 373(9682), 2215-2221.

[44] Tabák, A. G., Herder, C., Rathmann, W., et al.: Prediabetes: a high-risk state for diabetes development. Lancet, 2012, 379(9833), 2279-2290.

[45] Lasserson, D. S., Glasziou, P., Perera, R., et al.: Optimal insulin regimens in type 2 diabetes mellitus: systematic review and metaanalyses. Diabetologia, 2009, 52(10), 1990-2000.

[46] Riddle, M. C., Rosenstock, J., Gerich, J.: The treat-to-target trial: randomized addition of glargine or human NPH insulin to oral therapy of type 2 diabetic patients. Diabetes Care, 2003, 26(11), 3080-3086.

[47] Holman, R. R., Thorne, K. I., Farmer, A. J., et al.: Addition of biphasic, prandial, or basal insulin to oral therapy in type 2 diabetes. N. Engl. J. Med., 2007, 357(17), 1716-1730.

[48] Holman, R. R., Farmer, A. J., Davies, M. J., et al.: Three-year efficacy of complex insulin regimens in type 2 diabetes. N. Engl. J. Med., 2009, 361(18), 1736-1747.

[49] Singh, S. R., Ahmad, F., Lal, A., et al.: Efficacy and safety of insulin analogues for the management of diabetes mellitus: a metaanalysis. CMAJ, 2009, 180(4), 385-397.

[50] Monami, M., Marchionni, N., Mannucci, E.: Long-acting insulin analogues versus NPH human insulin in type 2 diabetes: a metaanalysis. Diabetes Res. Clin. Pract., 2008, 81(2), 184-189.

[51] Heise, T., Pieber, T. R.: Towards peakless, reproducible and longacting insulins. An assessment of the basal analogues based on isoglycaemic clamp studies. Diabetes Obes. Metab., 2007, 9(5), 648-659.

[52] Garber, A. J.: Restaging insulin therapy for patients with type 2 diabetes. Diabetes Obes. Metab., 2009, 11(Suppl. 5), 1-5.

[53] Mullins, P., Sharplin, P., Yki-Jarvinen, H., et al.: Negative binomial meta-regression analysis of combined glycosylated hemoglobin and hypoglycemia outcomes across eleven Phase III and IV studies of insulin glargine compared with neutral protamine Hagedorn insulin in type 1 and type 2 diabetes mellitus. Clin. Ther., 2007, 29(8), 1607-1619.

[54] Ritzel, R., Roussel, R., Bolli, G. B., et al.: Patient-level meta-analysis of EDITION 1, 2 and 3: glycaemic control and hypoglycaemia with new insulin glargine $300 \mathrm{U} / \mathrm{mL}$ versus glargine 100 $\mathrm{U} / \mathrm{mL}$ in people with type 2 diabetes. Diabetes Obes. Metab., 
Article first published online: 16 Jun 2015. DOI: 10.1111/ dom.12485. [Epub ahead of print]

[55] Domján, B., Ferencz, V., Tabak, A. G.: New medications and treatments in diabetes. [Új gyógyszerek, terápiás lehetôségek a cukorbetegek ellátásában.] Medical Tribune, 2014, 12, 14-16. [Hungarian]

[56] Steinstraesser, A., Schmidt, R., Bergmann, K., et al.: Investigational new insulin glargine $300 \mathrm{U} / \mathrm{ml}$ has the same metabolism as insulin glargine $100 \mathrm{U} / \mathrm{ml}$. Diabetes Obes. Metab., 2014, 16(9), 873-876.

[57] Becker, R. H., Dahmen, R., Bergmann, K., et al.: New insulin glargine 300 Units $\mathrm{mL}^{-1}$ provides a more even activity profile and prolonged glycemic control at steady state compared with insulin glargine 100 Units. $\mathrm{mL}^{-1}$. Diabetes Care, 2015, 38(4), 637-643.

[58] Wright, A., Burden, A. C., Paisey, R. B., et al.: Sulfonylurea inadequacy: efficacy of addition of insulin over 6 years in patients with type 2 diabetes in the U.K. Prospective Diabetes Study (UKPDS 57). Diabetes Care, 2002, 25(2), 330-336.
[59] Turner, R. C., Cull, C. A., Frighi, V., et al., for the UK Prospective Diabetes Study (UKPDS) Group: Glycemic control with diet, sulfonylurea, metformin, or insulin in patients with type 2 diabetes mellitus: progressive requirement for multiple therapies (UKPDS 49). JAMA, 1999, 281(21), 2005-2012.

[60] Tamás, G.: Insulin treatment. In: Halmos, T., Jermendy, G. (eds.): Diabetes mellitus. Theory and practice. [Inzulinkezelés. In: Halmos, T., Jermendy, G. (szerk.): Diabetes mellitus. Elmélet és klinikum.] Medicina Könyvkiadó, Budapest, 2002. [Hungarian]

[61] Kahn, S. E., Cooper, M. E., Del Prato, S.: Pathophysiology and treatment of type 2 diabetes: perspectives on the past, present, and future. Lancet, 2014, 383(9922), 1068-1083.

[62] Berger, M.: Towards more physiological insulin therapy in the 1990s. A comment. Diabetes Res. Clin. Pract., 1989, 6(4), S25S31.

(Ferencz Viktória dr., Budapest, Korányi S. u. 2/A, 1083 e-mail: viki.ferencz@gmail.com)

\section{Tisztelt Szerzőink, Olvasóink!}

Az Orvosi Hetilapban megjelenö/megjelent közlemények elérhetőségére több lehetőség kínálkozik.

Rendelhető különlenyomat, melynek áráról bővebben a www.akkrt.hu honlapon (Folyóirat Szerzőknek, Különlenyomat menüpont alatt) vagy Szerkesztöségünkben tájékozódhatnak.

A közlemények megvásárolhatók pdf-formátumban is, illetve igényelhető Optional Open Article (www.oopenart.com).

Adott dij ellenében az online közlemények bárki számára hozzáférhetök honlapunkon (a közlemények külön linket kapnak, így más oldalról is linkelhetővé válnak).

Bővebb információ a hirdetes@akkrt.hu címen vagy különlenyomat rendelése esetén a Szerkesztőségtől kérhető. 